Sains Malaysiana 49(11)(2020): 2755-2761

http://dx.doi.org/10.17576/jsm-2020-4911-14

\title{
Association of STAT4 rs7574865 with Sysceptibility to Juvenile Onset Systemic Lupus Erythematous in Pakistani Population
}

(Perkaitan STAT4 rs7574865 dengan Kebolehlihatan terhadap Penyakit Lupus Erythematous Sistemik Juvenil pada Penduduk Pakistan)

\author{
Bashir RasheedA*, Ali hira, Malik Saira, Munir Neelma, Haq Rukhama, Naz Shagufta \& Altaf Imran
}

\section{ABSTRACT}

Association of STAT4 (signal transducer and activator of transcription4) haplotype tagged by single nucleotide polymorphism (SNP) rs7574865 with systemic lupus erythematosus (SLE) was reported in different populations. This study was aimed to investigate a genetic association between STAT4 single nucleotide polymorphism (rs7574865) with susceptibility and clinical features of systemic lupus erythematosus in Pakistani population. A total of 75 clinically diagnosed individuals affected with SLE were enrolled from Children's Hospital and Institute of Child Health Lahore. Sixty-eight healthy individuals of same ethnicity were also enrolled for this study. Clinical assessment of patients was done with the help of clinical features suggestive for SLE and some diagnostic tests specific for the disease were performed. SNP rs 7574865 was genotyped by allele specific tetra ARMS PCR assay to check and compare the genotypic allele frequencies between SLE patients and healthy controls. Different statistical analysis ChiSquare, Fisher's exact tests and binary Logistic Regression is performed to determine association of risk alleles with SLE in Pakistani population. $p$ value less than $>0.05$ consider significant. This study showed the frequency of GG (28\%), TT (12\%), and GT alleles $(60 \%)$ in SLE patients while controls showed allele frequencies of GG (5\%), TT (29\%) and GT (64\%), respectively. The results showed that GG genotype and $G$ allele in STAT4 rs 7574865 was the risk allele for SLE while Tallele proved to be the protective one for disease susceptibility when compared with healthy controls genotypic frequencies. This study suggests the strong association of SNP rs 7574865 in STAT4 with the risk of SLE in Pakistani population. However, G allele showed no association with organ damage and immune disorder of SLE.

Keywords: Single nucleotide polymorphism; STAT4; systemic lupus erythematosus

ABSTRAK

Perkaitan antara STAT4 (transduser isyarat dan pengaktif transkripsi4) haplotip bertanda oleh polimorfisme nukleotida tunggal (SNP) rs7574865 dengan lupus eritematosus sistemik (SLE) dilaporkan dalam populasi berbeza. Kajian ini bertujuan untuk mengkaji hubungan genetik antara polimorfisme nukleotida tunggal STAT4 (rs7574865) dengan kerentanan dan ciri klinikal lupus eritematosus sistemik dalam populasi Pakistan. Seramai 75 individu yang didiagnosis secara klinikal terkesan oleh SLE telah didaftarkan dari Hospital Kanak-kanak dan Institut Kesihatan Kanak-kanak Lahore. Enam puluh lapan individu sihat daripada etnik yang sama juga telah didaftarkan untuk kajian ini. Penilaian klinikal pesakit dilakukan dengan bantuan ciri klinikal untuk SLE dan beberapa ujian diagnostik khusus untuk penyakit tersebut dijalankan. SNP rs7574865 digenotip dengan alel khusus tetra asai ARMS PCR untuk menyemak dan membandingkan frekuensi alel genotip antara pesakit SLE dan kawalan sihat. Analisis statistik ChiSquare berbeza, ujian tepat Fisher dan Regresi Logistik binari dijalankan untuk menentukan hubungan risiko alel dengan SLE dalam populasi Pakistan. Nilai p kurang daripada $>0.05$ dianggap signifikan. Kajian ini menunjukkan frekuensi alel GG (28\%), TT (12\%) dan GT (60\%) pada pesakit SLE sementara kawalan menunjukkan frekuensi alel GG (5\%), TT (29\%) dan GT (64\%). Hasil kajian menunjukkan bahawa genotip GG dan alel G pada STAT4 rs 7574865 adalah alel risiko untuk SLE sementara alel T terbukti menjadi pelindung bagi kerentanan penyakit apabila dibandingkan dengan frekuensi genotipik kawalan sihat. Kajian ini mencadangkan perkaitan yang kuat oleh SNP rs 7574865 dalam STAT4 dengan risiko SLE dalam populasi Pakistan. Walau bagaimanapun, alel G tidak menunjukkan kaitan dengan kerosakan organ dan gangguan imun SLE.

Kata kunci: Lupus eritematosus sistemik; polimorfisme nukleotida tunggal; STAT4 


\section{INTRODUCTION}

Systemic Lupus Erythematosus (SLE) is an autoimmune disease categorized by intolerance to body antigens and resulting in production of high amount of autoantibodies directed against DNA and other cellular components. Defective apoptosis of cells and their disturbed removal results in overall increase in target tissues and circulation and served as initiative base for autoimmune response (Piotr et al. 2012). Systemic Lupus Erythematosus (SLE) is a heterogenic inflammatory disorder. It is shown by various genetic, environmental, and pathogenic background that collectively evokes innate and adaptive immune responses with resultant immune complex deposition, overproduction of autoantibodies, inflammatory cytokine release, and disease onset (Su et al. 2012). Cell death pathway alterations are the potential source of auto antigens formation. Auto antigens released mainly from defective clearance of apoptotic cells presented by follicular dendritic cells to auto reactive B cells to generate autoantibodies that mimics the loss of self-tolerance an ultimate feature of SLE (Mahajan et al. 2016). SLE disease is immunologically characterized by presence of auto-immune complexes, antinuclear immunoglobulin and elevating level of complement proteins (Munoz et al. 2005). It is a multiorgan disorder in which autoimmune complexes causes severe harm especially to kidneys, skin, heart, joints, lungs, liver, and blood vessels (Cruz 2006). SLE immune responses act as disease activity markers. Eleven classification criteria have been established by the American College of Rheumatology any four of these clinical features confirms the classification as SLE (Kimberly et al. 2008). Moreover, SLE is manifested by various clinical features that include discoid rash, malar rash, arthritis, and photosensitivity, nephritis along with renal, neurologic, hematologic, immunologic, and mucocutaneous manifestations (Kuenkele et al. 2003). In a more recent review, the female-to-male ratio in the children was reported to be about 12:1.2. Age distribution for the disease ranged between 2 years and 80 years of age and in some cases older (Tsao \& Grossman 2001). The global prevalence of SLE is approximately 20-70/100,000 people (Habibi et al. 2011; Marti et al. 2008). Prevalence of SLE in the United States is reported to be 53 per 100,000 while other estimations ranged from 322,000 to over 1 million (Candace et al. 2013). In some population like Japan has lower prevalence rate of 3.2-19.3 (Kawasaki et al. 2008). However, the prevalence of SLE in Pakistan is still unknown. By recent studies and the number of genes identified so far, we would estimate that there are roughly 20-50 of these, of which MHC (Harley et al. 2009), ITGAM (Hom et al. 2008), IRF5 (Gabriel et al. 2002), BLK, and STAT4 (Kimberly et al. 2008) provides overwhelming evidence for SLE, strong evidence described by PTPN22 (Zervou et al. 2011) and FCGR2A (Kimberly et al. 2008) while good evidence evaluated by TNFSF4 as suggested by different studies. Various case control association studies have been done in United States (Kimberly et al. 2008), Japan (Taylor et al. 2008), Sweden (Morales et al. 2008), Mexico and North China (Han et al. 2009) who found the risk allele of STAT4 gene SNP rs7574865 associated with SLE.

STAT4 is a transcription factor (Munoz et al. 2005). It is required for the signal transduction of multiple cytokines including interleukin-12 (IL-12), IL-15, and IL-23 and therefore, is important in the differentiation of a Th1 cell immune response and has also been reported to be involved in the development of Th17 cells that are responsible for autoimmunity associated inflammation (Cruz 2006). STAT4 gene SNP rs 7574865 polymorphism on chromosome $2 \mathrm{q}$ had shown strong risk for SLE (Abelson et al. 2009). This SNP along with other variants located in the third intron of the gene could influence transcription of gene by damaging a transcription factor binding (Zhao et al. 2009). A case control association study designed on Japanese population to test whether STAT1-STAT4 region is associated with SLE and examined the potential genetic contribution of STAT4. They analysed 52 tag single nucleotide polymorphisms (SNPs) encompassing the STAT1-STAT4 region and also for associated SNPs and identified rs7574865, rs11889341, and rs10168266 in STAT4 showed most significant association. Subsequent association studies also confirmed a strong association of the subgroups of SLE with nephritis and anti-doublestranded DNA antibodies (Kawasaki et al. 2008). A cohort reported on Swedish Caucasian SLE patients to elucidate the genetic components of lupus nephritis and identified association between the SNPs rs11889341, rs7574865, rs 7568275, and rs7582694 of STAT4 gene and the development of lupus nephritis (Bolin et al. 2013). A study conducted on Coulombians aimed to identify that either TRAF1/C5 variants or STAT4 influence the risk of developing rheumatoid arthritis and systemic lupus erythematosus and their data strengthen the suggestion that STAT4 rs7574865 polymorphism is susceptibility factor for RA and SLE but TRAF1/C5 had no effect for the disease (Morales et al. 2008). A large SLE population is screened in Mexico by conducting a study on STAT4 association with SLE through two independent effects that correlate with gene expression and act additively with IRF5 to increase the disease risk. They evaluated that out of four SNPs rs7574865, rs1467199, rs3821236 and rs7574865, three SNPs rs3821236, rs3024866 and rs7574865 remained significant throughout the study (Abelson et al. 2009). In Chinese Northern Han population, STAT4 association with systemic lupus erythematosus was investigated and showed TT genotype and T allele in STAT4 rs7574869 were the susceptibility factors for SLE, especially for male SLE patients (Yin et al. 2010).

In the present study, we investigated the association of STAT4 SNP rs7574865 in SLE patients belong to in Pakistani population. 


\section{MATERIALS AND METHODS}

This case control study conducted after taking approval from Institutional review board (IRB) of Department of Biotechnology, Lahore College for Women University, Lahore, Pakistan. Blood samples (3-5 mL) were taken from SLE patients recruited from Medical general ward (M-1) and Nephrology ward of Children's Hospital \& Institute of Child Health Sciences, Lahore from September 2017 to September 2018. Written informed consent was obtained from parents on behalf of their young children. All basic parameters including duration of disease, age at disease, onset, and clinical features of disease were recorded. An inclusion criterion was clinical presentation of SLE including skin rash, photosensitivity, oral ulcer, arthritis, nephritis, serositis, and neuropsychiatric features of the patients. Blood samples of sixty five normal healthy controls of same ethnic groups with no familial history of SLE or any other autoimmune disease were collected for this study.

Total Genomic DNA of 75 affected and 65 healthy controls was extracted from peripheral blood leukocytes using a simple non organic blood extraction method that involves cell lysis, proteinase $\mathrm{K}$ digestion followed by used of salt extraction for the precipitation of contaminating proteins (Grimberg et al. 1989). Approximately 2ng of the genomic DNA was used to genotype each sample. Genotyping of STAT4 SNP rs7574865 was performed by Tetra ARMS PCR according to the manufacturer's protocols. PCR amplification was done using 2 sets of primers. The outer primer set included forward outer: 5'-ATCCACAAATTATATCTTTTCCATTTTTT-3' ( $410 \mathrm{~b} \mathrm{p} \mathrm{)} \mathrm{a} \mathrm{n} \mathrm{d} \mathrm{re} \mathrm{ver} \mathrm{s} \mathrm{e} \mathrm{o} \mathrm{u} \mathrm{t} \mathrm{e} \mathrm{r} \mathrm{:}$ 5'-GGAATTTTTGTTATGATGAAAATAGCTT-3' (410bp) while the inner primer sets comprised forward inner T allele: -AGTATGAAAAGTTGGTGACCAAAATATT$(180 \mathrm{bp})$ and reverse inner $G$ allele: -AATTCCACTGAAATAAGATAACCACTACTC- (288bp). (http://primer1.soton.ac.uk/primer1.html.) $12 \mu \mathrm{L}$ of PCR reaction was transferred to a $2 \%$ agarose gel and samples were electrophoresed at 110 volts for $30 \mathrm{~min}$. Bands were finally visualized by UV transilluminator. The amplified DNA bands of the specific STAT4 SNP rs7574865 primer showed common forward outer band of $410 \mathrm{bp}$ while $\mathrm{G}$ allelic band comprised of 288bp and T allelic band of 288bp (Figure 1).

\section{STATISTICAL ANALYSIS}

Statistical analysis was performed using SPSS 17.0 software (Armonk, US). The association between the genotype in patients compared to controls is analyzed by computing the Pearson chi-square $(\chi 2)$ and Fisher's exact test. Binary Logistic Regression is also performed to determine odds ratio for estimating relative measure of risk alleles with SLE in Pakistani population. In all statistical analyses, a 'p' value of less than 0.05 (95\% QI) was considered to be statistically significant.

\section{RESULTS}

In this study, among 75 patients, 15 patients were male and 80 were female patients. Age of SLE patients ranged from 5-16 years with average of $11.0 \pm 2.34$. Average age of male SLE patients was $11 \pm 2.34$ years while females were diagnosed at an average age of 11.2 \pm 2.25 . Major incidence of SLE was observed in age group of $11-13$ years, as $46 \%$ patients belonged to this group. Trends of incidence for SLE in different age groups are shown in Table 1.

SNP rs 7574865 was genotyped in 75 SLE patients and 68 healthy controls genomic DNA samples. The rs7574865 G allele (28\%) in the patients was significantly higher than the control group (5\%). The rs7574865 TT homozygous genotype frequency was lower in patients than controls and counted as $12 \%$ and $29 \%$, respectively. GG genotype of the STAT4 rs7574865 was significantly associated with an increased risk of SLE when TT was taken as a reference considering the control group (Figure 2). By the regression analysis on this data, it is concluded that GG allele is related with increased risk of disease ( $\mathrm{OR}=$ 7.807 ) and this risk is statistically significant ( $\mathrm{p}$-value $=$ 0.020) (Table 3), while TT allele is a protective genotype for SLE patients in Pakistan. It was investigated whether risk GG genotype of STAT4 rs7574865 was correlated with specific clinical manifestations of SLE and found no significant correlation between frequencies of $\mathrm{G}$ allele in STAT4 rs7574865 and specific clinical features associated with SLE (Table 2).

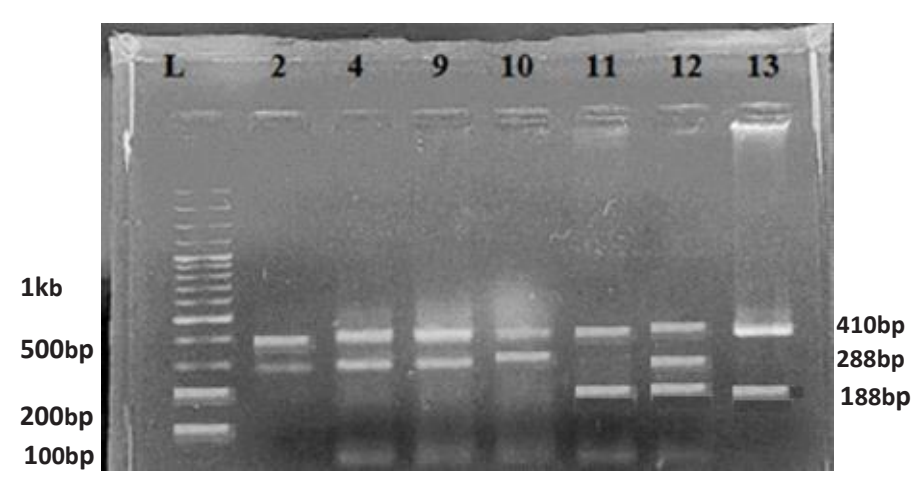

FIGURE 1. Some of the amplified PCR products of SLE cases resolved on $2 \%$ agarose gel for SNP rs7574865. L represent the Gene ruler ladder 


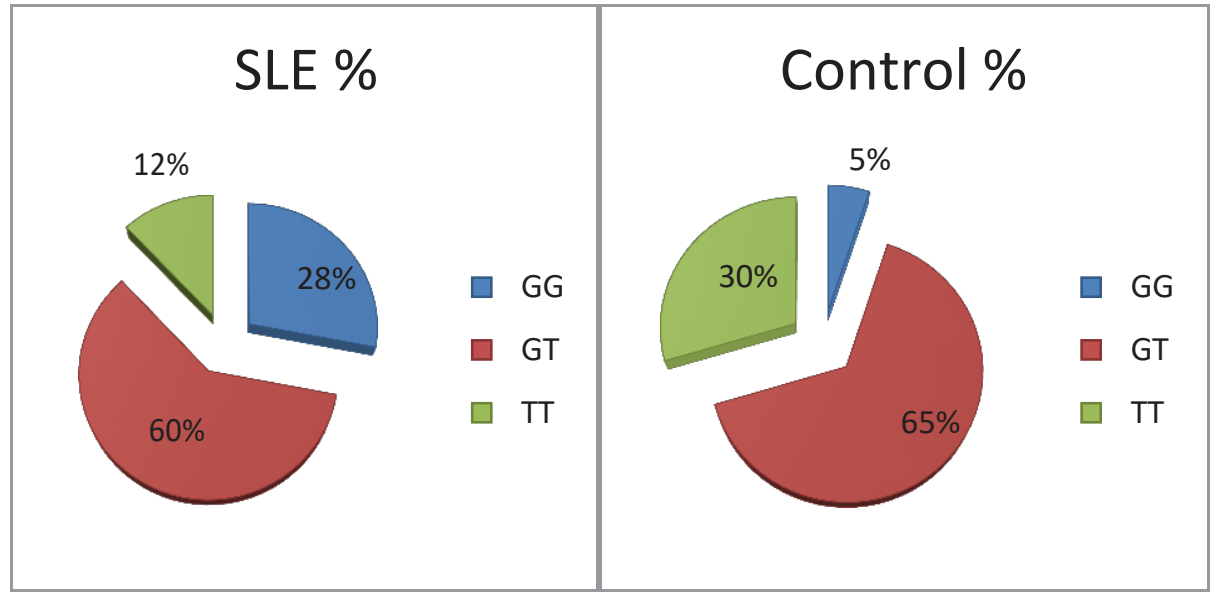

FIGURE 2. Pie charts showing genotypic frequencies in SLE patients and controls for STAT4 SNP (rs7574865)

TABLE 1. Age stratification in patients with SLE

\begin{tabular}{ccccc}
\hline $\begin{array}{c}\text { Age groups of } \\
\text { SLE patients }\end{array}$ & $\begin{array}{c}\text { Male } \\
\mathrm{n}=15(20 \%)\end{array}$ & $\begin{array}{c}\text { Female } \\
\mathrm{n}=60(80 \%)\end{array}$ & $\begin{array}{c}\text { Total } \\
\mathrm{n}=75(100 \%)\end{array}$ & $\begin{array}{c}\text { Percentage } \\
\text { Average: } 11 \pm 2.59\end{array}$ \\
\hline $5-7$ & 1 & Average: $11.2 \pm 2.25$ & Average: $11.3 \pm 2.3$ & $6.6 \%$ \\
$8-10$ & 5 & 17 & 5 & $29.3 \%$ \\
$11-13$ & 5 & 30 & 35 & $46 \%$ \\
$14-16$ & 3 & 7 & 10 & $\%$ \\
\hline
\end{tabular}

TABLE 2. Frequencies of STAT4 SNP (rs7574865) genotypes in various clinical features and laboratory investigations

\begin{tabular}{|c|c|c|c|c|c|}
\hline \multirow{2}{*}{$\begin{array}{l}\text { Sr. } \\
\text { no }\end{array}$} & \multirow[t]{2}{*}{ Clinical features } & \multirow{2}{*}{$\begin{array}{c}\text { Frequency } \\
\qquad \mathrm{N}(\%)\end{array}$} & \multicolumn{3}{|c|}{ rs7574865 Genotype distribution } \\
\hline & & & GT $(\%)$ & GG $(\%)$ & TT $(\%)$ \\
\hline 1. & Malar rash & $69(92 \%)$ & $45(65 \%)$ & $9(13 \%)$ & $15(21 \%)$ \\
\hline 2. & Discoid rash & $54(72 \%)$ & $36(66 \%)$ & $6(11 \%)$ & $15(27 \%)$ \\
\hline 3. & Photosensitivity & $30(40 \%)$ & $18(60 \%)$ & $3(10 \%)$ & $9(30 \%)$ \\
\hline 4. & Oral ulcers & $48(64 \%)$ & $27(56 \%)$ & $9(12 \%)$ & $15(31 \%)$ \\
\hline 5. & Arthritis & $69(92 \%)$ & $39(56 \%)$ & $9(13 \%)$ & $21(30 \%)$ \\
\hline 6. & Neurological disorder & $21(28 \%)$ & $15(71 \%)$ & $3(14 \%)$ & $3(14 \%)$ \\
\hline 7. & Nephritis & $57(76 \%)$ & $33(57 \%)$ & $9(15 \%)$ & $15(26 \%)$ \\
\hline 8. & Serositis & $42(56 \%)$ & $30(71 \%)$ & $6(14 \%)$ & $6(14 \%)$ \\
\hline 9. & ANA + ive & $75(100 \%)$ & $45(60 \%)$ & $9(12 \%)$ & $21(28 \%)$ \\
\hline
\end{tabular}


TABLE 3. Association between alleles and SNP rs7574865 of STAT4gene

\begin{tabular}{|c|c|c|c|c|c|c|c|c|c|}
\hline \multirow[t]{2}{*}{ Genotypes } & & \multirow[t]{2}{*}{$\mathrm{B}$} & \multirow[t]{2}{*}{ S.E. } & \multirow[t]{2}{*}{ Wald } & \multirow[t]{2}{*}{ Deference } & \multirow{2}{*}{$\begin{array}{c}\text { Significance } \\
\text { (p value) }\end{array}$} & \multirow{2}{*}{$\begin{array}{l}\text { Exp (B) } \\
\text { Lower }\end{array}$} & \multicolumn{2}{|c|}{ 95\% C.I.for EXP(B) } \\
\hline & & & & & & & & Upper & \\
\hline \multirow{4}{*}{ Step $1^{\mathrm{a}}$} & AlleleGG & 2.055 & .886 & 5.378 & 1 & $.020 *$ & 7.807 & 1.375 & 44.340 \\
\hline & AlleleGT & -.065 & .850 & .006 & 1 & $.939 *$ & .937 & .177 & 4.962 \\
\hline & AlleleTT & -1.131 & .873 & 1.676 & 1 & $.195^{*}$ & .323 & .058 & 1.788 \\
\hline & Constant & .092 & .826 & .012 & 1 & $.911 *$ & 1.096 & & \\
\hline
\end{tabular}

a. Variable(s) entered on step 1: Allele GG, Allele GT, Allele TT

*Logistic regression analysis values

Bold: statistically significant

\section{DISCUSSION}

During the past few decades' genome association studies identified various genes associated with SLE confirmed among different populations (Harley et al. 2009). Prevalence of SLE was most commonly reported in Hispanics, African, and American populations (Hoffecker et al. 2013). In our study, seventy-five patients enrolled with age ranges from 5 to 16 years as this study included patients of younger age and early adulthood with an average of 11.0 \pm 2.34 . Female to male ratio is $4: 1$ and more female between 11 and 13 years were identified affected with SLE as this is the age of endogenous sex hormones production that strongly predisposes to autoimmune diseases (Munoz et al. 2005). Our data is justified by several studies conducted in India (Malaviya et al. 1997), Saudia Arabia (AlArfaj \& Khalil 2009), Iran (Mirkazemi et al. 2013) and Oman (Al-Maini et al. 2003). However, no study was found that included SLE patients with age ranging between 5 and 16 years. STAT4 SNP rs7574865 located in third intron of the gene was strongly associated with SLE in the various populations (Candace et al. 2013; Kawasaki et al. 2008; Morales et al. 2008; Taylor et al. 2008; Zhao et al. 2009). In the present study, SNP rs 7574865 of STAT4 was significantly associated with predisposition to SLE in Pakistani population. Frequency of homozygous GG genotype is increased in patients affected with SLE (28\%) as compared to healthy control $(5 \%)$ and frequency of homozygous TT genotype is declined to $(12 \%)$ in SLE patient while increased percentage of TT genotype is shown in controls $(29 \%)$. These present finding were consistent to conclude that $\mathrm{G}$ allele of GG genotype was referred to as risk allele and in accordance T allele of TT genotype was referred to as the protective one. However, heterozygous GT genotypes seem no consistency with any protective or risk phenomena for healthy controls $(64 \%)$ and SLE patient $(60 \%)$ and make no interpretable findings about disease. These results were not consistent with the reports from Iranian (Mirkazemi et al. 2013),
Northern Chinese (Yin et al. 2010), Coulombians (Abelson et al. 2009) and Japanese studies (Hom et al. 2008) which reported that TT genotype of STAT4 SNP rs7574865 as risk factor for predisposition to SLE. Reasonable differences between our results and previous studies were may be due to different race and ethnic groups. They might be due to different sample sizes in multiple studies.

Severity of clinical manifestation in SLE varies with age, sex, race, and geographical distribution (Marti et al. 2008). The present study proposed that minor $G$ allele of STAT4 SNP rs7574865 does not correlated with SLE specific clinical features. Previous studies conducted in USA (Candace et al. 2013), Europe and Sweden (Siggurdson et al. 2008) showed stronger association of SLE with nephritis and anti dsDNA antibody production. All the mentioned findings done in different populations were contradictory to our study and possible explanations for these findings were might be genetic heterogeneity, variability of clinical features specified for SLE and patient interaction with different environmental factors that varies among different populations. However, a case control study conducted in Iran also showed that risk T allele in their population does not correlates with clinical manifestations suggestive of SLE (Mirkazemi et al. 2013). In China, results data augmented that risk $\mathrm{T}$ allele does not show any association with SLE related heamatological and clinical investigations (Yin et al. 2010). The results of these studies are correlated with this study.

\section{CONCLUSION}

It is concluded from this study that there is strong association of SNP rs7574865 in STAT4 Gene with the risk of SLE in Pakistani population. The GG genotype or $G$ allele in rs7574865 was found in correlation with risk of SLE. However, the G allele in rs 7574865 showed no association with organ damage and immune disorders of SLE. 


\section{REFERENCES}

Abelson, A.K., Delgado-Vega, A.M., Kozyrev, S.V., Sánchez, E., Velázquez-Cruz, R., Eriksson, N., Wojcik, J., Linga Reddy, M.V., Lima, G., D’Alfonso, S., Migliaresi S., Baca, V., Orozco, L., Witte, T. \& Ortego-Centeno, N. 2009. STAT4 associates with SLE through two independent effects that correlate with gene expression and act additively with IRF5 to increase risk. Ann. Rheum. Dis. 68(11) 1746-1753.

AlArfaj, A.S. \& Khalil, N. 2009. Clinical and immunological manifestations in 624 SLE patients in Saudi Arabia. Lupus 18(5): 465-473.

Al-Maini, M.H., El-Ageb, E.M., Al-Wahaibi, S.S., Al-Farsi, Y. \& Richens, E.R. 2003. Demographic, autoimmune, and clinical profiles of patients with systemic lupus erythematosus in Oman. Rheumatol. Int. 23(4): 186-191.

Bolin, K., Sandling, J.K., Zickert, A. \& Jonsen, A. 2013. Association of STAT4 polymorphism with severe renal insufficiency in lupus nephritis. PLoS ONE 8(12): e84450.

Candace, H., Feldman, L.T. \& Hiraki, J.K. 2013. Epidemiology and sociodemographics of systemic lupus erythematosus and lupus nephritis among us adults with medicaid coverage, 2000-2004. Arthritis Rhem. 65(3): 753-763.

Cruz, D.P. 2006. Systemic lupus erythematosus. British Medical Journal 332(7546): 890-894.

Gabriel, S.B., Schaffner, S.F. \& Nguyen, H. 2002. The structure of haplotype blocks in the human genome. Science 296(78): 2225-2229.

Grimberg, J., Nawoschik, S., Belluscio, L., McKee, R. \& Turck, A. 1989. A simple and efficient non-organic procedure for the isolation of genomic DNA from blood. Nucleic Acids Res. 17(20): 8390-8390.

Habibi, S., Saleem, M.A. \& Ramanan, A.V. 2011. Juvenile systemic lupus erythematosus: Review of clinical features and management. Indian Pediatr. 48(11): 879-887.

Han, J.W., Zheng, H.F., Cui, Y., Sun, L.D., Ye, D.Q. \& Hu, Z. 2009. Genome-wide association study in a Chinese Han population identifies nine new susceptibility loci for systemic lupus erythematosus. Nat Genet. 41(8): 1234-1237.

Harley, I.T., Kaufman, K.M. \& Langefeld, C.D. 2009. Genetic susceptibility to SLE. Molecular Biology Reports 10: 285290.

Hoffecker, B.M., Raffield, L.M., Kamen, D.L. \& Nowling, T.K. 2013. Systemic lupus erythematosus and vitamin D deficiency are associated with shorter telomere length among African Americans: A case-control study. PLoS ONE 8(5): e63725.

Hom, G., Graham, R.R. \& Modrek, B. 2008. Association of systemic lupus erythematosus with C8orf13-BLK and ITGAM-ITGAX. N. Engl. J. Med. 358(8): 900-909.

Kawasaki, A., Ito, I., Hikami, K., Ohashi, J. \& Hayashi, T. 2008. Role of STAT4 polymorphisms in systemic lupus erythematosus in a Japanese population: A case-control association study of the STAT1-STAT4 region. Arthritis Res. Ther. 10(5): R113.

Kimberly, E.T., Elaine, F., Remmers, T. \& Annette, L. 2008. Specificity of the STAT4 genetic association for severe disease manifestations of systemic lupus erythematosus. PLoS Genet. 4: 5e.
Kuenkele, S., Beyer, T.D., Voll, R.E., Kalden, J.R. \& Herrmann, M. 2003. Impaired clearance of apoptotic cells in systemic lupus erythematosus: Challenge of $\mathrm{T}$ and $\mathrm{B}$ cell tolerance. Cur. Rheumatol. Rep. 5: 175-177.

Mahajan, A., Herrmann, M. \& Muñoz, L.E. 2016. Clearance deficiency and cell death pathways: A model for the pathogenesis of SLE. Front Immunol. 7: 35.

Malaviya, A.N., Chandrasekaran, A.N., Kumar, A. \& Shamar, P.N. 1997. Systemic lupus erythematosus in India. Lupus 6: 690-700.

Marti, J., Varade, A., Marquez, M.C. \& Cenit, L. 2008. Association of the STAT4 gene with increased susceptibility for some immune-mediated diseases. Arthritis Rheum. 58(9): 2598-2602.

Mirkazemi, S., Akbarian, M., Jamshidi, A.R. \& Mansouri, R. 2013. Association of STAT4 rs 7574865 with susceptibility to systemic lupus erythematosus in Iranian population. Inflammation 36(6): 1548-1552.

Morales, R.J., Gonzalez, C.I. \& Ramrez, G. 2008. STAT4 but not TRAF1/C5 variants influence the risk of developing rheumatoid arthritis and systemic lupus erythematosus in Colombians. Genes Immun. 4: 1466-4879.

Munoz, L.E., Gaipl, U., Franz, S. \& Sheriff, A. 2005. SLE a disease of clearance deficiency? Rheumatology 44: 11011107.

Piotr, P., Margarita, L., Mariusz, W. \& Marzena, O.P. 2012. Contribution of STAT4 gene single-nucleotide polymorphism to systemic lupus erythematosus in the Polish population. Mol. Biol. Rep. 39: 8861-8866.

Sigurdsson, S., Nordmark, G., Garnier, S., Grundberg, E., Kwan, T. \& Nilsson, O. 2008. A risk haplotype of STAT4 for systemic lupus erythematosus is over-expressed, correlates with anti-dsDNA and shows additive effects with two risk alleles of IRF5. Hum. Mol. Genet. 17: 2868-2876.

Su, D.L., Lu, Z.M., Shen, M.N., Li, X. \& Sun, L.Y. 2012. Roles of pro -and anti-inflammatory cytokines in the pathogenesis of SLE. J. Biomed. Biotechnol. 2012: 347141.

Taylor, K.E., Remmers, E.F., Lee, A.T., Ortmann, W.A. \& Plenge, R.M. 2008. Specificity of the STAT4 genetic association for severe disease manifestations of systemic lupus erythematosus. PLoS Genet. 4: 5e.

Tsao, B.P. \& Grossman, J.M. 2001. Genetics and systemic lupus erythematosus. Cur. Rheumatol. Rep. 3: 183-190.

Yin, S., Zhao, Y., Xu, L., Guo, J.P., Jiang, Q., Liu, X.Y., Zhang, F.C., Zheng, Y., Li, X.X., Song, H., Huang, C.B., Huang, Y.H., Wang, T., Pan, S.S., Li, C., Liu, X., Zhu, L., Zhang, C.F. \& Li, Z.G. 2010. Variation in STAT4 is associated with systemic lupus erythematosus in Chinese Northern Han population. Chinese Medical Journal 123(22): 3173-3177.

Zervou, M.I., Vazgiourakis, V.M., Yilmaz, N., Kontaki, E. \& Trouw, L. 2011. TRAF1/C5, eNOS, C1q, but not STAT4 and PTPN22 gene polymorphisms are associated with genetic susceptibility to systemic lupus erythematosus in Turkey. Hum. Immunol. 72(12): 1210-1213.

Zhao, M., Hirankarn, N., Lau, C.S. \& Mok, C.C. 2009. Population differences in SLE susceptibility genes: STAT4 and BLK, but not PXK, are associated with systemic lupus erythematosus in Hong Kong Chinese. Genes Immun. 10: 219-226. 
Bashir Rasheeda*, Ali Hira, Munir Neelma, Haq Rukhama \& Naz Shagufta

Department of Biotechnology

Lahore College for Women University

Lahore

Pakistan

Malik Saira

Department of Microbiology and Molecular Genetics University of the Punjab

Lahore

Pakistan
Altaf Imran

Institute of Microbiology

University of Veterinary and Animal Sciences

Lahore

Pakistan

*Corresponding author; email: rashidasbs@yahoo.com

Received: 30 October 2019

Accepted: 10 June 2020 